\title{
Suggestions on Perfecting Index Systems of Building a Well-off Society in an All-round Way
}

\author{
Lv Jian, Li Yi \\ Department of Social Science North China Institute of Aerospace Engineering, Langfang, China \\ baiyunfei790221@163.com, friend_mail@126.com
}

\begin{abstract}
The index systems are not only the tools to evaluate existing practice results, but also the guides to the future development direction and development way of practical activities. The 18th CPC National Congress in 2012 put forward "ensuring to achieve great goals of building a well-off society in an all-round way in 2020 ". The construction of a well-off society enters a critical stage, so the original evaluation standards must change with gradual advancement of the construction goal of a well-off society.

Index Terms - comprehensive construction of a well-off society, Index systems, perfection

The index systems are not only the tools to evaluate existing practice results, but also the guides to the future development direction and development way of practical activities. From "adequate food and clothing" to "well-off families", from "an overall well-off society" to " a comprehensive well-off society ", then to " a well-off society in an all-round way, promoting step by step the construction of the target shows the change process of evaluation standards of building a well-off society.
\end{abstract}

\section{The Significance of Perfecting Index Systems of Building a Well-Off Society in an All-Round Way}

\section{A. Index systems with evaluation functions can evaluate} scientifically implememtation degree of building a well-off society.

In order to measure and evaluate the basic situation of building a well-off society, and to judge whether development goal is reasonable and measurement is proper, perfecting index systems of building a well-off society in an all-round way is to look for and establish a relatively objective and acceptable evaluation systems. By contrasting, we can objectively understand our own development conditions and development level.

B. Predictive functions of index systems can provide a scientific basis for realizing a well-off society in an allround way.

Scientific and reasonable index systems can provide a scientific basis for the establishment of the phased development goals of building well-off society in different regions. From comprehensive evaluation results and the change trend of different indicators, the basic situation and direction of building a well-off society in a given area can be predicted. It is the basic foundation of economic and social development plans, and also the breakthrough point to find and solve problems in order to improve the government's ruling ability and effect.
C. The guiding functions of index systems can provide impetus for the realization of a well-off society in an all-round way.

By scientifically quantifying and refining the basic requirement of a well-off society, and by changing the virtual into the real, the abstract to the concrete, the macro principles of a well-off society can be divided into recognizable and operational standards. In this way, all levels of government and society as a whole cab be clear about the direction.

\section{The Basis of Index Systems of Building a Well-Off Society in an All-Round Way}

\section{A. Theoretical basis}

One is the party's platform and literature. From the concepts "being well-off", " well-off families" and "Chinese modernization" that Deng xiaoping first put forward in the end of 1979, to formally realizing "being well-off " as a milestone of the national economy and social development in the 12th CPC National Congress in 1982, to the statement of a well-off society in an all-round way in 16th and 17th CPC National Congress, especially to the goal of "building a well-off society in an all-round way" in 18th CPC National Congress in 2012, the theory of building a well-off society become more and more perfect. Second is the evaluation index systems of social development both at home and abroad. Relatively representative evaluation system in the world are index systems designed by the United Nations agencies and the World Bank, such as sustainable development index systems by Commission on Sustainable Development of the UN and index systems for the sustainable development by the World Bank, etc. Domestic research institutions, many experts and scholars also has carried out the comprehensive research on evaluation systems of a well-off society in an all-round, and put forward many versions of index systems. Now the most popular are monitoring index systems made by National Bureau of Statistics in 2008.

\section{B. Practical foundation}

Building a well-off society in an all-round way Speeds up obviously in recent years. It has entered a new stage that the rapid expansion of total quantity synchronizes with the improvement of quality benefit. According to the monitoring scheme of the comprehensive construction of well-off society published by statistics bureau in 2008, realization degree of national comprehensive construction of a well-off society reached $80.1 \%$ in $2011,20.5 \%$ higher than that of 2000 , and increased by $2.05 \%$ per year on average (see following chart). 
Table: realization degree of national construction of a well-off society in 2000-2010

\begin{tabular}{|c|c|c|c|c|c|c|}
\hline Year & 2000 & 2001 & 2002 & 2003 & 2004 & 2005 \\
\hline $\begin{array}{c}\text { Degree of } \\
\text { implementation(\%) }\end{array}$ & 59.6 & 60.7 & 61.8 & 63.0 & 64.8 & 67.2 \\
\hline Year & 2006 & 2007 & 2008 & 2009 & 2010 & - \\
\hline $\begin{array}{c}\text { Degree of } \\
\text { implementation(\%) }\end{array}$ & 69.9 & 72.8 & 74.7 & 77.5 & 80.1 & - \\
\hline
\end{tabular}

But with rapid process of the comprehensive construction of a well-off society, some problems and contradictions in the development become increasingly prominent. The first is the imbalance of regional development. The development of the regional gap is obvious, and development situations in eastern, central, western and northeast are gradient; The second is rural problems. The income gap of the urban and rural residents is widening clearly, and agricultural modernization will still take time. Issues of agriculture, farmer and rural area are still the focus of the comprehensive construction of a well-off society; The third is the economic structure and development mode. Vulgar development pattern transition caused by low innovation ability requires a process; The Fourth is resources and environment protection. Resources and environmental costs of economic development are still high. Resource utilization and environmental protection are facing great pressure.

\section{Adjustment Suggestions on Index Systems of Comprehensive Construction of a Well-Off Society}

\section{A. Index systems should reflect better the overall principles}

"Comprehensiveness" is critical to building a well-off society in an all-round way. Comprehensiveness is one basic principle in designing index systems. First, from the perspective of the overall layout of the social development, the design of index systems should provide clear goals for the development of economy, politics, culture, society, ecology, natural environment and so on. Each indicator and its numerical requirements should be specific and objective. Especially in the existing index systems we must increase appropriately the reflection of democratic process, judicial credibility, citizens' cultural quality and social civilization degree, government management efficiency, living environment improvement. Weights should put on society, culture, ecological environment, etc. Second, from a specific level of social development, Comprehensiveness is reflected in the social development layout. Indicators such as economic development, not only reflect the speed of economic development, but also the development of balance, coordination and sustainability, balance between quality and quantity; Political development indicators, both reflect the perfection of democratic system and the richness of the forms, and more satisfaction degree of the citizens' democratic rights; Cultural development indicators should not only reflect the rich cultural products and the system improvement of public cultural services, and more the citizen civilized quality and the improvement of social civilization degree; Development indicators of people's living standards should not only reflect the improvement of residents' per capita income, especially the improvement of residents' purchasing power, but also development indicators to reflect fairness and justice in income distribution; Development indicators of ecological environment can both comprehensively and objectively reflect the current overall situation of our ecological system, and give a clear direction in building a resource-conserving, environment-friendly society.

\section{B. Index systems should embody better the people-oriented principle}

The ultimate goal of economic and social development is human development, and is to meet people's needs. The ultimate goal of building comprehensively a well-off society is to realize people's development in an all-round way. Therefore, the ultimate goal of the improvement of index systems of building a well-off society in an all-round way is to fully reveal and reflect people's development, in order to promote people's all-round development. When designing index systems and the reference standards, we should paid attention to three points; The first is people 's demands such as economy, politics, culture, natural ecological environment and social ecological environment; The second is people's own promotion of comprehensive quality, including ideological and moral qualities, scientific and cultural quality, psychological and physiological quality; The third is people's talents and their uses, that is to say, the comprehensive innovation ability of a given area, such as the investment of education, the protection of intellectual property rights, the investment of innovation, innovation environment, etc.

\section{Coordination of social development should be considered in the index systems}

Different elements of social development are interdependent and mutually related. when improving the index systems, we must give full consideration to the balance between different elements of social development. We Should not only consider the amount of GDP growth, but also consider the impact of this increase on the consumption of energy resources, natural and social ecological environment, and even people's development. At the same time, we must consider social effect, that is to say, fairness and justice. We should appropriately increase indicators that reflect social fair and balanced degrees of social and economic development, such as the Gene coefficient that reflect social security, social equity index, etc.

\section{Regional characteristics should be considered in the index systems}

Because of the history and reality and subjective factors and objective factors, regional differences and imbalance of China's economic and social development will exist for a long time. Coordination of regional development is a hard task for building a well-off society in an all-round way. Therefore, the regional characteristics and development reality should be considered fully in improving the index systems of a well-off society in an all-round way. On the one hand, the design of 
index systems has certain elasticity that not only gives play to the functions of evaluation, prediction and guidance, but also leaves some room for improving regional index systems. On the other hand, the reference standards should be neither too high nor too low, and regional reality must be taken into consideration.

\section{References}

[1] The statistical monitoring team of the comprehensive construction of a well-off society. The statistical monitoring report of the process in building a well-off society in an all-round way (2011). Journal of research world, 2011, (12): 3-7.
[2] Song Linfei. The Index System of China's Well-off Society and Its Evaluation, Nanjing social science, 2010, (1):6 14.

[3] Wang Shouzhi. Realizing goals of building a well-off society under the guidance of the scientific outlook on development to. Journal of Shanxi institute of socialism, 2012, (12): 10-15.

[4] Zhu Donghui. Index systems of influencing factors in the construction of a well-off society and is method research, an empirical analysis based on the process of building a well-off society in Hubei province. Journal of Hubei social sciences, 2013, (10): 61-64.

[5] Pan Fan, Yang jingying. The monitoring report of China's construction of a well-off society in an all-round in 2011. Beijing: social sciences press, 2011. 